\title{
Influence of Chemicals and Mechanical Control Methods on Parasite Dodder (Cuscuta planiflora) Controlling in Clover (Trifolium alexandrinum L.) Crops Emam, R. A. \\ Plant Protection Department, Faculty of Agriculture, Al-Azhar University branch Assiut. \\ *Corresponding author: Dr. Rabee Ali Emam. \\ E-mail: rabee8104@gmail.com
}

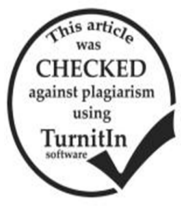

\begin{abstract}
The goal from these experiments were studied the effect of some chemical and mechanical methods of dodder weed control on the Egyptian clover field. The treatments comprised of spray pendimethalin herbicides (pre-emergence and after sowing) in three concentrations $(500,700$ and $900 \mathrm{ml} / \mathrm{Fed}$.) and three times application $(1,3$ and 7 DAS) followed by spray glyphosate alone after the first cutting in three concentration (50,70 and $90 \mathrm{ml} / \mathrm{Fed}$.) and three time application (7, 14 and $21 \mathrm{DAS})$, followed by, studies the influence of addition ammonium sulfate with (1\%) on the impact of glyphosate against $C$. planiflora in Egyptian clover in relation to dose and time of application after the first cutting of Egyptian clover. Phytotoxic of application rates and treatment time of glyphosate on Egyptian clover after the first cutting were studied. Results it could be concluded that, use of pendimethalin at 7 DAS was safe for Egyptian clover T. alexandrinum emergence as compared to its application as pre-emergence at 1 and 3 DAS and also effective in reducing C. planiflora emergence. Moreover, increasing dose of pendimethalin from 500 to $900 \mathrm{ml} / \mathrm{Fed}$. gave significantly decreased in the C. planiflora emergence but also caused phytotoxic to T. alexandrinum plants and reduced its population significantly. Using glyphosate herbicide at different doses were significantly affected the characteristic of dodder plants infested with clover crops. The fresh and dry weights of survival dodder plants were inversely related to the dose of herbicide. The higher the dose of herbicide used the more damage of dodder plants occurred.The mechanical methods -hand combing- management was the minimum effective in C. planiflora control with percent of reduction.
\end{abstract}

Keywords: chemical, pendimethaline, glyphosate, dodder, Egyptian clove, ammonium sulfate.

\section{INTRODUCTION}

(T.alexandrinum L.) is the main forage crops grown worldwide. Egyptian clover are extensively grown in irrigated regions through winter period Farah and Al-Abdul Salam, (2004). Dodder weed (Cuscuta planiflora), is known to be the major pest attacking the Egyptian clover in Egypt. Most dodder seeds germinate from March to May, one to three years after burial in the soil. Cudney et al., (1992) dodder is capable to cause the most intensive damage in newly formed perennial legume (clover or alfalfa) crops, which are the most frequent targets of dodder parasitism Dawson et al., (1994). Destruction done in these crops involves generally of decreased fresh biomass to crop alfalfa, which may be reach to more than $50 \%$ dodder and decreased in seed production by more than $50 \%$ of alfalfa. The control of dodder is very major in increasing the quality of alfalfa and yield, and approaches included preventive measures against contamination (Tepe, 2014). Until now there is no clear stratagem in the control of dodder weed. Only traditional or old methods are usually used by the farmers such as herbicides, solarization, trap, resistant varieties and catch crops or cultural methods (distance between plants, sowing delayed etc). Burning is usually used in the case of heavy infestation. Chemicals are used successfully to control dodder plants in some border countries. The flaming and mowing able to management dodder as cultural methods, but these practices have the potential to injure the crop and decrease yield Cudneyet al., (1992). Field dodder controlling could be succeeded using combined, chemical, mechanical, cultural and preventive methods that aim at control of existing populations prior to seed production to avoid further dispersal of seeds. Chemical control is the utmost intensively studied method of dodder managements Parker, (1991). Glyphosate can selectively control dodder at rates of 0.075 to $0.150 \mathrm{~kg}$ ai/ha in alfalfa Dawson, (1989). The field work described in this study is an attempt to through some light on some chemical method on dodder control moreover the factors which govern the effect of time of application and different concentrations of pendimethaline and glyphosate on the behavior of dodder weed when the plants growing together with foliage crop (T. alexandrinum $\mathrm{L}$ ).

\section{MATERIALS AND METHODS}

Field experiments were conducted at a farmer's field in Faculty of Agriculture Al-Azhar University branch Assuite during successive season 2018, to study the influence of two herbicides (pendimethalin and glyphosate) in field dodder control and its impact on (fresh, dry and length plant) of Egyptian clover cultivars. Other than weed control, usual agriculture practices were done according to Ministry of Agriculture recommended in all the trials. Before sowing of Egyptian clover, fifteen Cuscuta seeds $/ \mathrm{m}^{2}$ were uniformly published adjacent the soil surface $(2-3 \mathrm{~cm}$ depth) in each plot (Except in Cuscuta free plots). The Cuscuta free as control and Cuscuta infested were also kept for comparison. Egyptian clover (cv. Vardan) was sown by distribution in the first week of October during the year with a seed rate of $30 \mathrm{~kg} / \mathrm{ha}$. The amount of water required to provide sufficient spray liquid was found to be 200 liters/fed. The herbicides, glyphosate (Roundup 48\%) and pendimethaline (Stomp 0.36\%) were sprayed with knapsack sprayer. Number of $C$. planiflora and clover emerged $/ \mathrm{m}^{2}$ were recorded at 30 days after sowing (DAS). Except Cuscuta, all the weeds were removed from the plots by hand combing as and when required. The first cutting was ready at 60 DAS and following two cuttings were done at 30 days intervals when the crop attained the height of around $45 \mathrm{~cm}$ from the ground. The cuttings were applied at about $5-7 \mathrm{~cm}$ height for well quick growth. A sample of ten plants from dodder and ten plants from clover plants were collected at random from each plot to estimate some of growth characters. The characters which were estimated were: characters (plant length, fresh weight, dry Weight and number of branch). Phytotoxic symptoms on plants were recorded in one week after application of chemicals. Observations for the specific parameters like chlorosis, necrosis, wilting, vein clearing, leaf scorch and redness of 
leaf margin were taken using the scale $0: 0-00,1: 1-10,2: 11-$ 20, 3: 21-30, 4: 31-40, 5: 41-50, 6: 51-60, 7: 61-70, 8:71-80, 9: 81-90, 10: 91-100. Also, phytotoxicity symptoms were recorded under field conditions Venkatarao, (2017). The total fodder yield contains the weight of Cuscuta vines as it was hard to remove it from the host plants..In this study certain treatments were used as follows:

1-Control (Egyptian clover were infection with Cuscuta and not controlling).

2-Control or healthy plants (Egyptian clover were not infection with Cuscuta).

3-Spraying pendimethalin herbicide with three concentrations (50, 70 and $90 \mathrm{ml} / \mathrm{Fed}$.) after sowing and pre - emergence of Egyptian clover and three timing of application 1,3 and 7 days.

4-Glyphosate was applied after the first cutting by hand sprayer at three concentrations $(50,70$ and $90 \mathrm{ml} / \mathrm{Fed}$.) and three timing of application (7, 14 and 21 days after the first cutting).

5-Synergism of glyphosate by addition ammonium sulfate (1\%) and Spraying with three concentration of glyphosate $(50,70$ and $90 \mathrm{ml} / \mathrm{Fed}$.) and three timing of application (7, 14 and 21 days after the first cutting) by hand sprayer.

6-Hand combing (Cuscuta removing by hand)

7- Phytotoxic of application rates and treatment time of glyphosate on Egyptian clover after first cutting.

The analysis of variance was used for the two experiments (using MSTAT-C) according to Snedecor and Cochran, (1982).

\section{RESULTS AND DISCUSSION}

1. Effect of application time and treatment rates of pendimethalin (after sowing and pre-emergence) on emerged number of Cuscuta and Egyptian clover.

Results in Table (1) show that, treatments of pendimethalin at 7 DAS was harmless for Egyptian clover T. alexandrinum emergence as compared to its application as pre-emergence at 1 and 3 DAS and also successful in decreasing Cuscuta emergence. Moreover, increasing dose of pendimethalin from 500 to $900 \mathrm{ml} / \mathrm{Fed}$. produced significantly reduced the Cuscuta ( $C$. planiflora) emergence but also caused phytotoxic to $T$. alexandrinum crop and reduced its population significantly. These results were fully supported by Mishra (2012) mentioned that, rising concentrations of pendimethalin from 500 to 1000 $\mathrm{ml} /$ ha did not appearance affected on the clover plant population, but irrespective of the pendimethalin doses, there was around $50 \%$ reduction in clover population as compared to untreated control because of the phytotoxic effect of pendimethalin when applied as pre-emergence and at 7 DAS. Cuscuta emergence decreased significantly with increase in pendimethalin doses. The high emerged number of Egyptian clover at7 days were 372,305 and 197 while the high emerged number of Cuscuta were 110, 62 and 43 for 500,700 , and $900 \mathrm{ml} / \mathrm{Fed}$. respectively.

Table 1. Effect of application time and treatment rates of pendimethalin (after sowing and preemergence) on emerged number of Cuscuta and Egyptian clover emerged $/ \mathrm{m}^{2}$ at $30 \mathrm{DAS}$.

\begin{tabular}{|c|c|c|c|c|c|c|}
\hline \multirow{4}{*}{$\begin{array}{l}\text { Time of } \\
\text { application } \\
\text { (DAS)* }\end{array}$} & \multicolumn{3}{|c|}{ Egyptian clover } & \multicolumn{3}{|c|}{ Cuscuta } \\
\hline & \multicolumn{6}{|c|}{ Treatments rates } \\
\hline & 500 & 700 & 900 & 500 & 700 & 900 \\
\hline & \multicolumn{6}{|c|}{ ml/Fed. ml/Fed. ml/Fed. ml/Fed.ml/Fed. ml/Fed } \\
\hline$\overline{1}$ & 150 & 120 & 90 & 40 & 30 & 20 \\
\hline 3 & 230 & 180 & 153 & 87 & 53 & 32 \\
\hline 7 & 372 & 305 & 197 & 110 & 62 & 43 \\
\hline Control & \multicolumn{3}{|c|}{70} & \multicolumn{3}{|c|}{280.3} \\
\hline Healthy plants & \multicolumn{3}{|c|}{400} & \multicolumn{3}{|c|}{0} \\
\hline
\end{tabular}

*DAS = days after sowing and pre-emergence.

1. Effect of pendimethalin herbicide concentrations on fresh and dry weight on dodder weed g/m2 (after sowing and pre emergence by 7 days).

Data in table (2) show the effect of pendimethalin herbicide treatments on fresh and dry weight of Egyptian clover dodder at 15, 30 and 45 days after treatments. The data revealed that the $C$. planiflora was very sensitive to pendimethalin herbicide. All tested concentrations from pendimethalin herbicide caused deleterious effects to $C$. planiflora, but the concentrations differed in these effects. The concentration $900 \mathrm{ml}$ from pendimethaline was superior and the most effective treatments used on dodder followed by 700 and $500 \mathrm{ml}$ when used as a spray application (after sowing and pre emergence by 7days). These concentration recorded the highest control after 45 days for fresh weight and dry weight. General average in fresh weight and dry weight were (504.5 and 91.9), (605 and99.5) and (691.8 and 119.7 ) to 900,700 and $500 \mathrm{ml} / \mathrm{Fed}$. compared with control (391.8 and 556.7), respectively.

In other hand, the mechanical methods -hand combing- management was the minimum effective in $C$. planiflora control with percent of reduction for fresh weight and dry Weight 3970.2 and 556.7, respectively in compared with control treatment. These results are in agreement with that of Liu et al., (1990) mentioned that, pendimethalin inhibited the cells of germinated Cuscuta seedlings and the percent of reduction data of $C$. planiflora were only slightly affected by the hand combing treatment when compared with other experimented herbicides. Therefore, management $C$. planiflora by hand combing was not enough to control C. planiflora weeds.

Table 2. Effect of pendimethalin herbicide treatment on dry and fresh weight on dodder weed $\mathrm{g} / \mathrm{m}^{2}$ (after sowing and pre emergence by 7 days).

\begin{tabular}{lcccccccc}
\hline \multirow{2}{*}{ Treatments } & \multicolumn{2}{c}{ 15 Days } & \multicolumn{2}{c}{ 30 Days } & \multicolumn{2}{c}{ 45 Days } & \multicolumn{2}{c}{ General average } \\
\cline { 2 - 9 } & F.W. & D.W. & F.W. & D.W. & F.W. & D.W & F.W & D.W \\
\hline $900 \mathrm{ml} /$ Fed. & 580.3 & 61.2 & 427.8 & 91.2 & 505.4 & 123.3 & 504.5 & 91.9 \\
$700 \mathrm{ml} /$ Fed. & 698.7 & 68.3 & 423.9 & 97.6 & 693.5 & 132.5 & 605.4 & 99.5 \\
$500 \mathrm{ml} /$ Fed. & 763.8 & 83.6 & 501.2 & 117.8 & 810.4 & 157.8 & 691.8 & 119.7 \\
Hand combing & 2138 & 301.6 & 23202.1 & 187.6 & 3050.4 & 307.3 & 9463.5 & 265.5 \\
Control & 3241.5 & 478.6 & 3862.3 & 573.2 & 4806.7 & 618.2 & 3970.2 & 556.7 \\
Healthy plants & 0 & 0 & 0 & 0 & 0 & 0 & & \\
\hline
\end{tabular}

F.W. =Fresh weight $\quad$ D.W. $=$ Dry Weight 
2. Effect of pendimethalin treatments on some growth characters of Egyptian clover (T. alexandrinum L.) $\mathrm{g} / \mathrm{m}^{2}$ (after sowing and pre emergence by 7 days).

Data shown in table (2) effect of three concentrations from pendimethalin on dry weight and plant length at 60,90 and harvest days (after sowing and pre emergence by 7days). All tested concentrations from pendimethalin increased the dry weight and plant length as compared to the control treatment. General average in plant high and dry weight were (82.1 and 4.3), (75.1 and3.3) and (68.7 and 3) to 900,700 and $500 \mathrm{ml} / \mathrm{Fed}$. compared with control (51.8 and 1.3), respectively. The hand combing management was the least effective in $C$. planiflora control with percent of reduction for fresh weight and dry Weight 57.8 and 2.1, respectively in compared to the control treatment. This increasing in dry weight under the infested control treatment might be attributed to the negative effect of different weeds on Egyptian clover plant growth which may be occurred as a result of the competition between Egyptian clover plants and weeds. These results are similar with that obtained by Soliman, (2002) he reported that parasitic weed not only deprives the host plants of nutrients but also inhibits growth.

Table3. Effect of pendimethalin control treatments on some growth characters of Egyptian clover ( $T$. alexandrinum $\mathrm{L}$.) $\mathrm{g} / \mathrm{m}^{2}$ (after sowing and pre emergence by 7 days).

\begin{tabular}{|c|c|c|c|c|c|c|c|c|}
\hline \multirow[b]{2}{*}{ Treatments } & \multicolumn{2}{|c|}{60 Days } & \multicolumn{2}{|c|}{90 Days } & \multicolumn{2}{|c|}{ At harvest } & \multicolumn{2}{|c|}{ General average } \\
\hline & $\begin{array}{l}\text { P.H. } \\
\text { (cm) }\end{array}$ & $\begin{array}{l}\text { D.W. } \\
\text { Plant }\end{array}$ & $\begin{array}{l}\text { P.H. } \\
\text { (cm) }\end{array}$ & $\begin{array}{l}\text { D.W. } \\
\text { Plant }\end{array}$ & $\begin{array}{l}\text { P.H. } \\
\text { (cm) }\end{array}$ & $\begin{array}{l}\text { D.W. } \\
\text { Plant }\end{array}$ & $\begin{array}{l}\text { P.H. } \\
\text { (cm) }\end{array}$ & $\begin{array}{l}\text { D.W. } \\
\text { Plant }\end{array}$ \\
\hline $900 \mathrm{ml} / \mathrm{Fed}$. & 53.3 & 0.45 & 81.7 & 5.7 & 111.3 & 6.8 & 82.1 & 4.3 \\
\hline $700 \mathrm{ml} /$ Fed. & 47.1 & 0.4 & 79.8 & 4.3 & 98.5 & 5.1 & 75.1 & 3.3 \\
\hline $500 \mathrm{ml} /$ Fed. & 43.6 & 0.4 & 71.2 & 3.8 & 91.3 & 4.8 & 68.7 & 3 \\
\hline Hand combing & 38.7 & 0.29 & 61.6 & 2.59 & 73.2 & 3.4 & 57.8 & 2.1 \\
\hline Control (infested) & 35.1 & 0.21 & 55.4 & 1.41 & 64.9 & 2.4 & 51.8 & 1.3 \\
\hline Healthy plants & 60.5 & 0.51 & 94.6 & 6.2 & 117.2 & 7.6 & 90.8 & 4.8 \\
\hline
\end{tabular}

D.W. $=$ Dry Weight P.H. $=$ Plant High

2. Impact of glyphosate against C. planiflora in Egyptian clover in relation to dose and time of application after the first cutting of Egyptian clover.

Table (4) shows that using glyphosate herbicide at different doses were significantly affected the characteristic of dodder plants infested with clover crops. The fresh and dry weights of survival dodder plants were inversely related to the dose of herbicide. The higher the dose of herbicide used the more damage of dodder plants occurred. Application of glyphosate at 7 and 14 DAS were significantly affected the characteristic of dodder plants infested with clover crops. In spite of, unaffected on characteristic of dodder plants infested at 21 DAS in all concentrations.

Table 4. Impact of glyphosate herbicide against $C$. planiflorain Egyptian clover in relation to dose and time of applicationafter the first cutting of Egyptian clover.

\begin{tabular}{|c|c|c|c|c|c|}
\hline $\begin{array}{l}\text { Concentration } \\
\text { of glyphosate } \\
\text { ml/Fed. }\end{array}$ & $\begin{array}{c}\text { A.P } \\
\text { (Days) }\end{array}$ & $\begin{array}{l}\text { F.W. } \\
\text { g/plant }\end{array}$ & $\begin{array}{l}\text { D.W. } \\
\text { g/plant }\end{array}$ & $\begin{array}{l}\text { L.P. } \\
\text { (cm) }\end{array}$ & $\begin{array}{l}\text { N.B. } \\
\text { g/plant }\end{array}$ \\
\hline & 7 & 0.65 & 0.1 & 15.3 & 8.6 \\
\hline \multirow[t]{3}{*}{50} & 14 & 0.73 & 0.21 & 22.5 & 10.3 \\
\hline & 21 & 2.0 & 1.3 & 8.5 & 2.4 \\
\hline & 7 & Zero & Zero & 18.3 & 6.2 \\
\hline \multirow[t]{3}{*}{70} & 14 & 0.39 & 0.13 & 31.2 & 6.9 \\
\hline & 21 & 2.2 & 1.2 & 8.4 & 2.3 \\
\hline & 7 & Zero & Zero & 22.3 & 5.6 \\
\hline \multirow[t]{2}{*}{90} & 14 & 0.149 & 0.063 & 36.4 & 7.1 \\
\hline & 21 & 2.3 & 1.4 & 8.6 & 2.1 \\
\hline Control (infested) & & 2.1 & 1.3 & 8.6 & 2.3 \\
\hline Healthy plants & & - & - & 83.2 & 13.6 \\
\hline
\end{tabular}

These results were fully supported by Fer, (1983) who reported that using glyphosate high dose was more effect on dodder live plants. Plant height and branch numbers of clover plants were significantly reduced as the dose of herbicide increased. Also, the time application had a high significant effect on dodder dry Weight, fresh weight, number of branches and length of plant. The fresh weight of dodder plants infested at 7 days after spraying was significantly higher than those treated 14 days durations. Salim,(2011) who reported that glyphosate at $75-150 \mathrm{~g} / \mathrm{ha}$ and its analong sulfosate (touch-down) control dodder directly and through their systematic movement within the host phloem system. He added that glyphosate can be applied to clover after dodder cutting. Different doses and application of glyphosate used in Egyptian clover Abd-El-Hamid and Shebl, (2000). In contrast our resulting Dawson and Saghir,(1983) they found that the duration time of herbicide application was more effective on the control of dodder particularly 20 days after infestation on dodder.

3. Influence of addition ammonium sulfate with (1\%) on the impact of glyphosate against $C$. planiflora in Egyptian clover in relation to dose and time of application after the first cutting of Egyptian.

Data presented in table (5) showed that, application of glyphosate with ammonium sulfate with (1\%) significantly increased the impact of glyphosate against $C$. planiflora in Egyptian clover than glyphosate alone, in all dose and all time of application after the first cutting of Egyptian clover. This results are in agreement with those of Singh and Sharma, (2001) stat that, the application of ammonium sulfate with glyphosate, significantly increased weed control compared to glyphosate alone. Moreover, the enhancement in bio efficacy depends on both the weed species and the type of the adjuvant. An increase of herbicide ability on perennial horse nettle (Solanum carolinense L.) with the addition of ammonium sulfate to glyphosate was also decided by Plineet al., (2000). Glyphosate is often applied with 
ammonium sulfate in order to reduce water hardness and enhance herbicide activity De Ruiteret al., (1996) more specifically, common cations, form salts that are not readily absorbed by plants and bind strongly to glyphosate negatively charged molecules, Thelen et al., (1995).

Table 5. Influence of addition ammonium sulfate with (1\%) on the impact of glyphosate against $C$. planiflora in Egyptian clover in relation to dose and time of application after the first cutting of Egyptian.

\begin{tabular}{lccccc}
\hline $\begin{array}{l}\text { Concentration } \\
\text { of glyphosate }\end{array}$ & $\begin{array}{c}\text { A.P } \\
\text { (Days) }\end{array}$ & $\begin{array}{c}\text { F.W. } \\
\text { g/plant }\end{array}$ & $\begin{array}{c}\text { D.W. } \\
\text { g/plant }\end{array}$ & $\begin{array}{c}\text { L.P. } \\
\text { (cm) }\end{array}$ & $\begin{array}{c}\text { N.B. } \\
\text { g/plant }\end{array}$ \\
\hline $50 \mathrm{ml}$ & 7 & 0.41 & 0.01 & 9.1 & 6.4 \\
& 14 & 0.56 & 0.1 & 15.5 & 8.2 \\
& 21 & 2.2 & 1.4 & 8.9 & 2.3 \\
$70 \mathrm{ml}$ & 7 & Zero & Zero & Zero & Zero \\
& 14 & 0.21 & 0.01 & 12.2 & 4.9 \\
& 21 & 2.0 & 1.1 & 8.4 & 2.5 \\
$90 \mathrm{ml}$ & 7 & Zero & Zero & Zero & Zero \\
& 14 & Zero & Zero & Zero & Zero \\
& 21 & 2.0 & 1.3 & 8.9 & 2.4 \\
\hline Control(infested) & \multicolumn{7}{c}{2.1} & 1.3 & 8.6 & 2.3 \\
Healthy plants & \multicolumn{7}{c}{-} & - & 83.2 & 13.6 \\
\hline F.W.=Fresh weight & N.B=Number of branches \\
D.W.= Dry Weight & L.P=Length of Plant \\
A.P=Age plant after second cutting and appearance dodder in winter
\end{tabular}

4. Phytotoxicty of application rates and treatment time of glyphosate on Egyptian clover after first cutting.

Data in table (6) showed that, phytotoxic symptoms on Egyptian clover were seen to redness of leaf margin after application of concentrations (50, 70 and $90 \mathrm{ml} /$ Fed.) at 7 DAS in all concentrations and 14 days in concentrations 90 $\mathrm{ml} /$ Fed. Only but this phytotoxic none significantly compere with control. Theleaf scorch was founded after application of concentrations (70 and $90 \mathrm{ml} / \mathrm{Fed}$.) at 7 DAS in the two concentrations and 14 days in concentrations $90 \mathrm{ml} / \mathrm{Fed}$. only. The symptoms' chlorosis, necrosis, wilting and vein were not founded in any combination treatments. Theleaf scorch was founded at 0.1 for $70 \mathrm{ml}$ only in the same time were, 0.3 and 0.1 for $90 \mathrm{ml}$ at 7 and 14 days, respectively.Redness of leaf margin was foundedat 0.1 for 50 and $70 \mathrm{ml}$ at 7 days, moreover Redness of leaf margin were 0.3 and 0.1 for $90 \mathrm{ml}$ at 7 and 14 days, respectively.This results are in agreement with those of Salim (2011) decided that glyphosate produced a clears damage on dodder plants where as clover plants did not find any sign of damage had less effect on it.in general may bee say that, the superiority of herbicide treatments might be attributed to lower weed competition as a result of eliminating weeds and their negative impact on crop plants. Moreover, the all treatments accorded the lowest plant length of Egyptian clover plant as compared to the healthy plant treatment.

Table 6. Phytotoxic of application rates and treatment time of glyphosate on Egyptian clover after the first cutting.

\begin{tabular}{lccccccc}
\hline $\begin{array}{l}\text { Concentration of } \\
\text { herbicide ml/Fed. }\end{array}$ & $\begin{array}{c}\text { A.T. } \\
\text { (Days) }\end{array}$ & Chlorosis & Necrosis & Wilting & Vein & $\begin{array}{c}\text { Leaf } \\
\text { scorch }\end{array}$ & $\begin{array}{c}\text { Redness of } \\
\text { Leaf margin }\end{array}$ \\
\hline 50 & 7 & - & - & - & - & - & 0.1 \\
& 14 & - & - & - & - & - & - \\
70 & 21 & - & - & - & - & - & - \\
& 7 & - & - & - & - & 0.1 & 0.1 \\
& 14 & - & - & - & - & - & - \\
90 & 21 & - & - & - & - & - & - \\
& 7 & - & - & - & - & 0.3 & 0.3 \\
\hline Control & 14 & - & - & - & - & 0.1 & -1 \\
Healthy plants & 21 & - & - & - & - & - & - \\
\hline
\end{tabular}

\section{REFERENCES}

Abd El-Hamid, M.M. and Shebl, S.M. (2000).Weed control research. Section Field Crops Res. Institute, A. R. C. Giza, Egypt.

Cudney, D.W; Orloff, S.B. and Reints, J.S. (1992). An integrated weed management for the control of dodder (C. indecora) in alfalfa (M. sativa). Weed Technology 6: 603-606.

Dawson, J.H. (1989). Dodder (Cuscuta spp.) control in established alfalfa ( $M$. sativa) with glyphosate and SC-0224. Weed Technology, 3(4), 552-559.

Dawson,J.H. and Saghir, A.R. (1983). Herbicides applied to dodder (Cuscutas pp) after attachment to alfalfa ( $M$. sativa) Weed Science 31:465-471.

Dawson, J.H.; Musselman, L.J.; Wolswinkel, P. and Dorr, I. (1994). Biology and control of Cuscuta. Weed Science 6: 265-317.
De Ruiter, H.; Uffing, A.J. (1996). Meinen, E. Influence of surfactants and ammonium sulfate on glyphosate phytotoxicity to quack grass (Elytrigiarepens). Weed Technol.10, 803-808.

Farah, A.F. and Al-Abdulsalam, M.A. (2004). Effect of dodder (Cuscuta campestris Younker) on some legume crops. Scientific J. of King Faisal University (Basic and Applied Sciences) 5: 103-113.

Fer, A. (1983). Investigation of a new strategy for dodder using systemic herbicides. Results with labelled molecules in the laboratory (in French. In Compte Rendu de la 12e Conference du COLUMA, 179-186.

Liu, Z.Q.; Lecocq, F.M.; Fer, A. and Hallet, J.N. (1990). Comparative study of the effect of three herbicides (pendimethalin, propyzamide and linuron) on the cell proliferetaion in the shoot meristmetic region of dodder seedlings (Cuscuta lupuliformis Krock.). Annales des Sciences Naturelles Botaniqueet Biologie Vegetale 11: 1-8. 
Mishra, J.S. (2012). Management of dodder in lucerne and Egyptian clover. Indian J. of Weed Science 44(1): 6-10.

Parker, C. and Riches, C.R. (1993). Parasitic weeds of the world: Biology and control (p 332). Wallingford, UK: Cab International.

Pline, W.A.; Hatzios, K.K.and Hagood, E.S. (2000). Weed and herbicide-resistant soybean (Glycine max) response to glufosinate and glyphosate plus ammonium sulfate and pelargonic acid. Weed Technol. 14, 667-674.

Salim, H. A. (2011). Effect of glyphosat on dodder (Cuscuta sp) weed growth with clover ( $T$. alexandrinum L). Mesopotamia J. of Agric. 40, (3), 1-6.

Sendecor, G.W. and Cochran, W.G. (1980). Statistical Methods. 6th ed. Iawa State University Press., Ames., USA: 325-330.
Singh, M. and Sharma, S. (2001). Different adjuvant types and glyphosate efficacy on some weeds. Proc. Fla. State Hortic. Soc. 114, 132-135.

Soliman, I.E. (2002). Herbicidal activity evaluation of some herbicides used to control of dodder (Cuscuta spp.) in some field crops. Ph.D. thesis, Faculty of Agriculture Mansoura University, Egypt: 55-75.

Tepe, I.(2014). Yabancı Otlarla Mücadele. Sidas Medya, Publication No: 031, ISBN 978-605-5267-17-9, Izmir, Turkey.

Thelen, K.D.; Jackson, E.P. and Penner, D. (1995).The basis for the hard water antagonism of glyphosate activity.Weed Sci. 43, 541-548.

Venkatarao P.(2017). Evaluation of Compatibility of New Insecticides With Some Fungicides For Management of Late Leaf Spot, Phaeoisariopsis personata (Berk. and Curt.) of Groundnut. International J. of Agriculture Innovations and Research.5, (5): 714-719.

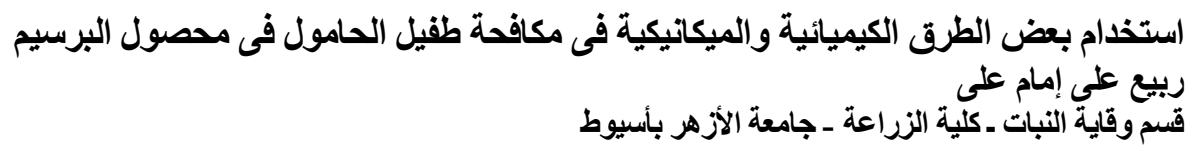

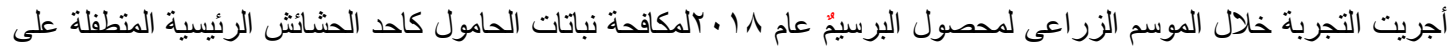

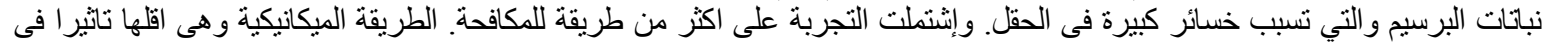

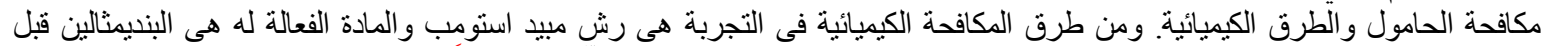

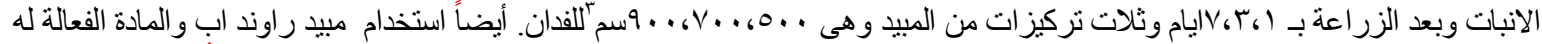

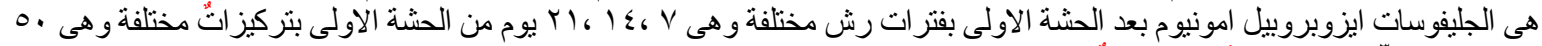

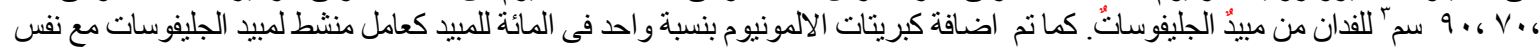

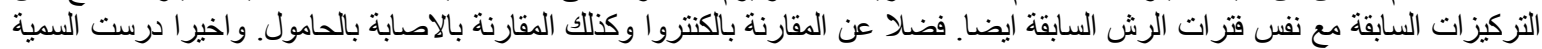

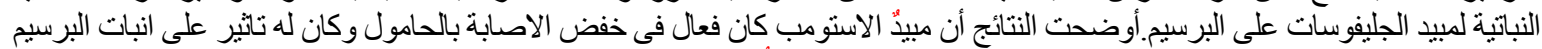

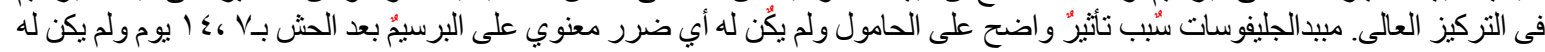

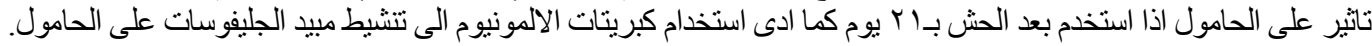

